\title{
THE COCHRANE LIBRARY JAKO PRZYKŁAD BAZY TYPU EVIDENCE BASED MEDICINE ${ }^{1}$
}

\author{
Agnieszka Łukomska-Kryger \\ Biblioteka Medyczna \\ Uniwersytetu Jagiellońskiego \\ Collegium Medicum
}

The Cochrane Library, Evidence Based Medicine, źródła informacji medycznej

Źródła informacji medycznej w Internecie można podzielić na kilka kategorii, są to m.in.: strony WWW organizacji medycznych, bazy danych, portale medyczne przeznaczone dla lekarzy oraz dla wszystkich internautów, strony WWW bibliotek medycznych, książki i czasopisma medyczne online. My zajmiemy się bazą Cochrane Library.

Początki bazy sięgają 1979 r., kiedy to epidemiolog Archie Cochrane zaproponował rozpatrywanie skuteczności procedur stosowanych w medycynie perinatalnej. Procedury te poddano randomizacji, potwierdzając skuteczność mniej niż połowy z nich. W 1993 r. powołano Cochrane Collaboration ${ }^{2}$, która miała na celu weryfikację stosowanych procedur, a wyniki obserwacji publikuje do dziś w The Cochrane Library.

The Cochrane Library ${ }^{3}$ to baza typu Evidence Based Medicine ${ }^{4}$, zbiór udokumentowanych prac, protokołów, metod, oraz analiz będących rezultatem pracy The Cochrane Collaboration. Zawiera systematyczne przeglady, jest niezwykle ważnym narzędziem informacyjnym pozwalającym dotrzeć między innymi do tzw. szarej literatury (zaliczymy do niej ekspertyzy, prace doktorskie, materiały ze zjazdów i konferencji itp.). Jest wydawana i uaktualniana cztery razy w roku przez Cochrane Collaboration. Rejestruje ok. pół miliona badań z grupą kontrolna, łącznie z badaniami opublikowanymi w książkach konferencyjnych lub innych źródłach nieindeksowanych w bazach danych. Zawiera ponad 4,5 tys. protokołów i przeglądów systematycznych, oceniających skuteczność różnorodnych interwencji zdrowotnych, wraz z systemem komentarzy i opinii krytycznych umożliwiających współpracę użytkowników w poprawie jakości przeglądów, prawie 6 tys. abstraktów innych przeglądów systematycznych oraz blisko 20 tys. abstraktów analiz ekonomicznych, poddanych krytycznej ocenie recenzentów

${ }^{1}$ Stan na 5 listopada 2009 r.

2 The Cochrane Collaboration - niezależna organizacja non profit lekarzy z różnych stron świata współpracujących ze sobą przy opracowywaniu tematów, które wchodzą w zbiór tejże biblioteki medycznej.

${ }^{3}$ The Cochrane Library. [online]. [dostęp: 5.11.2009]. Dostępny w World Wide Web: <http://www3.interscience. wiley.com/cgi-bin/mrwhome/106568753/HOME>.

${ }^{4}$ Evidence Based Medicine (EBM) - medycyna oparta na faktach. 
z brytyjskiego Centrum Przeglądów i Rozpowszechniania (NHS Centre for Reviews and Dissemination) $)^{5}$. Zawiera również ponad 6 tys. raportów oceny technologii medycznych, opracowanych przez członków Międzynarodowej Sieci Agencji Oceny Technologii Medycznych (The International Network of Agencies for Health Technology Assessment - INAHTA ${ }^{6}$.

Dostęp do bazy danych jest płatny, choć w niektórych krajach władze państwowe zapewniają bezpłatny dostęp dla swoich obywateli na zasadzie National Prevention, tj. bezpłatnego, nieograniczonego dostępu dla lekarzy, naukowców, pacjentów, jak np. w Wielkiej Brytanii, Australii, czy też Nowej Zelandii. Od 1 stycznia 2007 r. również obywatele polscy mogą bezpłatnie korzystać z bazy danych za pośrednictwem INAHTA . W lipcu 2009 r. Agencja Oceny Technologii Medycznych wystosowała komunikat, iż: „z dniem 31 lipca wygasa Narodowy Dostęp do Biblioteki Cochrane'a na 2009 r. Krok ten podyktowany jest ograniczeniem środków finansowych przekazanych na ten cel, jak również statystykami wykorzystania bazy w ramach Narodowego Dostępu (w okresie od 1 stycznia do 30 kwietnia br. system zarejestrował 3552 sesji użytkowników). W związku z powyższym kontynuacja dostępu na dotychczasowych zasadach jest nieuzasadniona".

Na Bibliotekę Cochrane składają się bazy:

- The Cochrane Database of Systematic Reviews - protokoły i przeglądy systematyczne oceniające skuteczność różnorodnych interwencji zdrowotnych,

- The Database of Abstracts of Reviews of Effectiveness - abstrakty przeglądów systematycznych, wzbogacone o ich krytyczną ocenę recenzentów z brytyjskiego Centre for Reviews and Dissemination,

- The Cochrane Central Register of Controlled Trials - informacje o odbywajacych się na całym świecie badaniach z grupą kontrolną,

- Cochrane Methodology Register - bibliografia publikacji dotyczących metodologii badań zastosowanych podczas badań z grupą kontrolna,

- Health Technology Assessment Database - informacje o zakończonych i prowadzonych w ramach INAHTA projektach oceny technologii medycznych w aspekcie medycznym, społecznym, etycznym i ekonomicznym,

- NHS Economic Evaluation Database - baza tworzona przez brytyjski Centre for Reviews and Dissemination; zawiera analizy ekonomiczne z całego świata oceniające relacje pomiędzy poniesionymi nakładami a efektywnością interwencji zdrowotnych ${ }^{8}$.

Informację na interesujące nas tematy można wyszukiwać według tematów lub za pomocą zaawansowanej wyszukiwarki. Znajduje się tu także dział Pomoc, zamieszczający porady dotyczące wyszukiwania i poruszania się po serwisie, multimedialne prezentacje strategii wyszukiwawczych i informacje o serwisie.

${ }^{5}$ Centrum Przeglądów i Rozpowszechniania. [online]. [dostęp: 13.06. 2009]. Dostępny w World Wide Web: <http://www.crd.york.ac.uk/crdweb/>.

${ }^{6}$ The International Network of Agencies for Health Technology Assessment - INAHTA. [online]. Agnie [dostęp: 13.06.2009]. Dostępny w World Wide Web: <http://www.inahta.org>

7 Ibidem.

${ }^{8}$ The Cochrane Library. [w:] Biblioteka Główna Uniwersytetu Medycznego w Białymstoku. [online]. [dostęp: 14.06.2009]. Dostępny w World Wide Web: <http://biblioteka.gumed.edu.pl/index.php?strona=195\#co>. 
W menu znajdują się również działy dla pracowników medycznych, badaczy, naukowców i pacjentów.

Aby móc korzystać z bazy bezplatnie, należy zarejestrować się; instrukcję można znaleźć na stronie Agencji Oceny Technologii Medycznych: http://www. aotm.gov.pl/.

Serwis można przeglądać z okna BROWSE poprzez opcje:

- Topic - wg tematyki,

- New Reviews - wg ostatnio wprowadzonych przeglądów baz,

- Updated Reviews - wg zaktualizowanych przeglądów baz,

- A-Z - wg przeglądów szeregowanych alfabetycznie,

- Review Groups - wg uszeregowanych nazw grup tematycznych dokonujących przeglądu.

Po wybraniu opcji, ukaże się lista przeglądów, gdzie każdy przegląd jest oznaczony danym symbolem określającym jego status zawierający:

- przegląd - rezultaty i dyskusje, meta-analiza i dane statystyczne, komentarze czytających oraz odpowiedź autorów,

- zarys przeglądu - wprowadzenie, cele i metodologia,

- przegląd opublikowany po raz pierwszy w najnowszym numerze The Cochrane Library,

- przegląd uaktualniony w najnowszym numerze The Cochrane Library,

- przeglad lub protokól wycofany - przyczyny wycofania podawane są indywidualnie dla każdego protokołu bądź przeglądu.

\section{Advanced Search | MeSHSearch I SearchHlstory I Saved Searches}

Enter a term below and click Search to continue.

Search For:

In:

To search using field labels (e.g. heart:ti) use the Search Histong page.

\begin{tabular}{|c|c|c|}
\hline & Enter search term 1 & Search All Text \\
\hline AND $M$ & Enter search term 2 & Record Title \\
\hline AND & Enter search term 3 & Author \\
\hline AND 1 & Enter search term 4 & Abstract \\
\hline AND & Enter search term 5 & Keywords \\
\hline
\end{tabular}

Sareh $\square$ Go directly to Search History

\section{Restrict Search by PI orluct}

All of The Cochrane Librany

Cochrane Database of Systematic Reviems (Cochrane Revienss)

Database of Abstracts of Reviens of Etfects (Other Reviens)

Jak większość serwisów internetowych The Cochrane Library posiada zarówno wyszukiwanie proste, jak i zaawansowane. By wyszukać bazę, która nas 
interesuje należy wybrać opcję SEARCH (Wyszukaj) lub skorzystać z opcji ADVANCED SEARCH (wyszukiwanie zaawansowane). Wyszukiwanie proste domyślnie szuka po tytule, słowach kluczowych, czy też streszczeniach - ale można również skorzystać z rozwijanego menu i wybrać termin nas interesujący. Chcąc zawęzić wyniki wyszukiwania, możemy skorzystać z menu ADVANCED SEARCH.

Mamy możliwość skorzystania z rozwijanego menu, możemy stosować standardowe operatory wyszukiwawcze (AND, OR, NOT), zastąpić końcówkę gwiazdka. Tak jak w pozostałych serwisach tego typu, możemy zawęzić wyszukiwanie do konkretnej bazy The Cochrane Library, czy do wybranego typu rekordu oraz roku publikacji. Istnieje również opcja SAVE SEARCH (Zachowaj Wyszukiwanie).

Można również wybrać opcję wyszukiwania przy wykorzystaniu MeSH SEARCH: należy podać deskryptor $\mathrm{MeSH}^{9}$, można skorzystać z trzech opcji: skorzystać z THESAURUS (słownik tezaurus - służący do sprawdzenia terminu), bądź też sprawdzić definicję terminu (DEFINITION). Jest również dostępna opcja Go To MeSH Trees, która pokazuje usytuowanie terminu w slowniku MeSH.

\section{Advanced Search I MeSH Search I Search History I Saved Searches}

Search bu qualifier alone

\section{Search for a MeSH descriptor}

Enter MeSH term:

Go To MeSH Trees

\section{Thessouns Defnition}

W panelu mamy również SEARCH HISTORY oraz SAVED SEARCHES ${ }^{10}$.

Wyniki wyszukiwania są prezentowane w postaci listy:

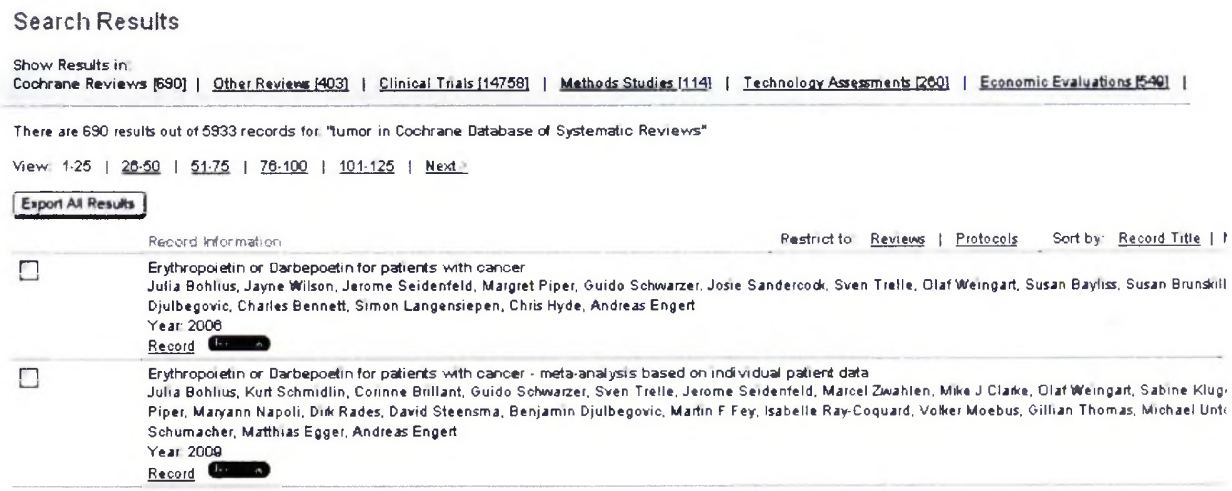

${ }^{9} \mathrm{MeSH}$ (Medical Subject Headings) - język haseł przedmiotowych z zakresu medycyny i nauk pokrewnych.

10 Seiffert J.: Cochrane Library Dostęp Narodowy: jak korzystać z bazy. [online]. [dostęp: 26.09.2009]. Dostępny w World Wide Web: <http://www.sum.edu.pl/e107_files/public/cochrane.doc>. 
Przeglądanie rekordu: W nagłówku rekordu znajdują się najważniejsze informacje, tj.: status rekordu, tytuł przeglądu, nazwiska autorów przeglądu, Digital Object Identifier (DOI), czyli Identyfikator Obiektu Cyfrowego - numer identyfikacyjny danych, a także data aktualizacji i właściwy sposób cytowania.

\begin{tabular}{|c|c|}
\hline $\begin{array}{l}\text { [Intervention Review] } \\
\text { Liver resection versus } \\
\text { other treatments for } \\
\text { neuroendocrine tumours } \\
\text { in patients with resectuble } \\
\text { liver metastases }\end{array}$ & $\begin{array}{l}\text { [Intervention Review] } \\
\text { Liver resection versus other treatments for neuroendociue tumo } \\
\text { resectable liver metastases } \\
\text { Kuninchi Selvan Gurvamy', Rajarajen Ramamoorthy', Dinesh Shama', Brian R Drvidson }{ }^{1}\end{array}$ \\
\hline $\begin{array}{l}\text { PDF } \\
\text { - Summary }(62 \mathrm{~K}) \\
\text { - Standard }(179 \mathrm{~K}) \\
\text { - Full }(207 \mathrm{~K})\end{array}$ & $\begin{array}{l}\text { Contact address. Kunnchi Selvan Gurusamy, Univensity Depart ment of Surgery, Royal Free Hospital and University C } \\
\text { Free Hospital, Pond Stret, London, NW3 2QG, UK Lurinchi2kghotmail com. (Editorial group: Cochrane Hepato-Bibi }\end{array}$ \\
\hline $\begin{array}{l}\text { - Abstract } \\
\text { - Plain language summary } \\
\text { The review } \\
\text { - Background }\end{array}$ & 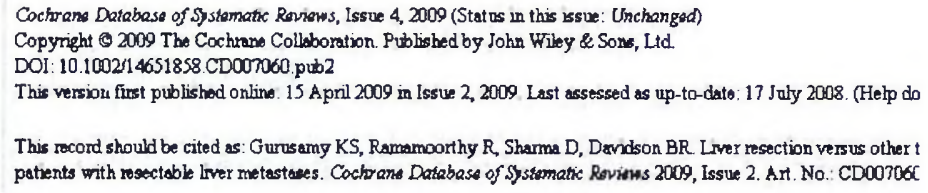 \\
\hline
\end{tabular}

\section{Uwagi końcowe}

The Cochrane Library ma już 16 lat. Powstanie jak i rozwój bazy był ważnym przedsięwzięciem dla środowiska medycznego. Przeszukiwanie bazy nie jest zajęciem czasochłonnym, po kilkudziesięciu sekundach mamy informację, czy dany temat był poruszany, czy też nie, co oszczędza czas korzystającym z bazy.

Rzetelna i pełna informacja w postaci przeglądów nie tylko ułatwia wytypowanie badań wiarygodnych, ale bywa również narzędziem do podjęcia konkretnej decyzji o finansowaniu jednostek zdrowia publicznego.

\section{Bibliografia}

1. Higgins JPT., Green S.: Cochrane Handbook for Systematic Reviews of Interventions 4.2.6 [updated September 2006]. [w:] The Cochrane Library. Issue 4. Chichester: John Wiley \& Sons, 2006.

2. Rosenbaum S. E., Glenton C., Cracknell J.: User experiences of evidence-based online resources for health professionals: User testing of The Cochrane Library. BMC „Medical Informatics and Decision Making" 2008, nr 8, s. 34. [online]. [dostęp: 26.09.2009]. Dostępny w World Wide Web: <http://www.pubmedcentral.nih.gov/articlerender.fcgi?tool=pmcentrez\&artid $=2529276>$.

3. Seiffert J.: Cochrane Library Dostęp Narodowy: jak korzystać z bazy. [online]. [dostęp: 26.09.2009]. Dostępny w World Wide Web: <http://www.sum.edu.pl/e107_files/public/ cochrane.doc>.

4. Starr M., Chalmers I.: The evolution of The Cochrane Library, 1988-2003. [online]. [dostęp: 26.09.2009]. Dostępny w World Wide Web: <http://www. update-software.com/history/clibhist.html>.

5. The Cochrane Library. [online]. [dostęp: 5.11.2009]. Dostępny w World Wide Web: <http:/ /www3.interscience.wiley.com/cgi-bin/mrwhome/106568753/HOME>.

6. The Cochrane Library. [w:] Biblioteka Główna Uniwersytetu Medycznego w Białymstoku. [online]. [dostęp: 14.06.2009]. Dostępny w World Wide Web: <http://biblioteka.gumed.edu.pl/index.php?strona $=195 \#$ co $>$. 
7. The International Network of Agencies for Health Technology Assessment - INAHTA. [online]. [dostęp: 13.06.2009]. Dostępny w World Wide Web: <http://www. inahta.org/>.

8. Wojczyńska M., Szloser M.: Źródła informacji medycznej w Internecie. „Biuletyn EBIB” 2008, nr 7. [online]. [dostęp: 15.07.2009]. Dostępny w World Wide Web: <http://www. ebib.info/2008/98/a.php?wojczynska_szloser>.

\section{Summary}

The article describes one of the medical information sources - i.e. the Cochrane Library, a bibliographic and factual database concerning evidencebased medicine. It comprises of a short historical introduction, background, and general rules of using this resource. 